\title{
A New Picorna-like Virus, PnPV, Isolated from Ficus Transparent Wing Moth, Perina nuda (Fabricius)
}

\author{
Chung-Hsiung Wang,* Chih-Yu Wu,* and Chu-Fang Lof \\ *Department of Entomol ogy and †Department of Zool ogy, National Taiwan University, Taipei 107, Taiwan, Republic of China
}

Received J uly 24, 1998; accepted December 18, 1998

\begin{abstract}
Two viruses, Perina nuda nucleopolyhedrovirus and a new picorna-like virus, were previously isolated from $P$. nuda larvae with flacherie. In this study the new picorna-like virus was characterized using physical and biochemical methods. This small virus appears to belong to the family Picornaviridae and we propose the name PnPV. PnPV can be propagated in its homogenous cell line, NTU-PN-HH. PnPV purified from the cell line resembles PnPV isolated from insects: under electron microscopy, it exhibits icosahedral symmetry, measures $30 \mathrm{~nm}$ in diameter, and has no envelope and no distinct surface structure in negatively stained preparations. In addition, we show here that PnPV has a buoyant density of $1.381 \mathrm{~g} / \mathrm{ml}$ in cesium chloride, the viral genome was composed of one single-stranded RNA molecule with a length of $10 \mathrm{~kb}$, and poly(A) tract and polyacrylamide gel electrophoresis of purified viral particles revealed three major $(31.5,29.7$, and 28.4 $\mathrm{kDa})$ and three minor $(27.0,24.5$, and $4.0 \mathrm{kDa})$ structural proteins. $\odot 1999$ Academic Press

Key Words: Perina nuda; NTU-PN-HH cell line; PnPV; picorna-like virus.
\end{abstract}

\section{INTRODUCTION}

Flacherie is a general term used to describe a larva that is suffering from dysentery and thus "flaccid," "flabby," "feeble," or "withered" (Tanada and Kaya, 1993). Although these symptoms can result from several causes, flacherie is usually microbial in origin and has been attributed to fungal, protozoan, baculoviral, and other viral infections. In the silkworm (Bombyx mori), it is caused by mixed infection by two viruses, a picornavirus and a densovirus (Tanada and Kaya, 1993). In Perina nuda larvae, flacherie is also considered to be caused by mixed infection by two viruses, in this case a picorna-like virus and PenuNPV (P. nuda nucleopolyhedrovirus) (Wang et al., 1998).

Using differential centrifugation and sucrose gradient centrifugation, Wang et al. (1998) first purified a small isometric picorna-like virus (30 $\mathrm{nm}$ in diameter) from the naturally infected larvae of the ficus transparent wing moth, P. nuda. It has been suggested that the picorna-like virus has an antagonistic effect on systemic PenuNPV infection in P. nuda larvae (Wang et al ., 1998) because histological and cytological studies of $P$. nuda larvae suffering from flacherie show heavy PenuNPV infection in epidermal cells, tracheal cells, and cells in most parts of the midgut and the fat body, whereas other tissues or organs show only a light or no infection with PenuNPV.

In the present paper, we attempt to confirm the taxonomic position of the picorna-like virus by establishing in vitro propagation in the homogenous cell line, NTU-PN-HH. We also investigate the characteristics of this virus.

\section{MATERIALS AND METHODS}

\section{Insects}

Larvae of P. nuda (Fabricius) were collected from the campus of National Taiwan University and fed on banyan leaves, Ficus spp., in the laboratory at $25^{\circ} \mathrm{C}$. Although some of the larvae collected from the field al ready showed the symptoms of flacherie, most of the larvae appeared to be healthy. However, symptoms also appeared in many of these apparently healthy specimens after they had been reared in the laboratory. As soon as flacherie was diagnosed in an insect, it was transferred to a refrigerator and stored at $-20^{\circ} \mathrm{C}$.

\section{Cell Lineand in Vitro Propagation}

NTU-PN-HH (Wang et al., 1996) cell line was established from P. nuda pupal ovary in our laboratory and maintained at $28^{\circ} \mathrm{C}$ in TNM-FH medium (Hink and Strauss, 1976) containing $50 \mathrm{IU} / \mathrm{ml}$ penicillin, $50 \mu \mathrm{g} / \mathrm{ml}$ streptomycin, and $1.25 \mu \mathrm{g} / \mathrm{ml}$ fungizone, supplemented with $10 \%$ fetal calf serum (FCS), which had been inactivated at $56^{\circ} \mathrm{C}$ for $30 \mathrm{~min}$.

The larvae with flacherie were surface-sterilized with $0.5 \%$ Clorax solution and dipped into serum-free TNM-FH medium containing antibiotics and fungizone 
in homogenizer. The homogenant was centrifuged at $2000 \mathrm{~g}$ for $30 \mathrm{~min}$ and then at $15,000 \mathrm{~g}$ for $1 \mathrm{~h}$. The suspension was filtrated with $0.45-\mu \mathrm{m}$ and then $0.2-\mu \mathrm{m}$ millipore filters and, finally, the filtrates were checked by negative staining preparation for electron microscope and also by $10^{-5}$ and $10^{-8}$ limiting dilution. The NPV-free filtrates were used as inocula. Monolayers of NTU-PN-HH log-phase cells $\left(1 \times 10^{6}\right.$ cells) in $25-\mathrm{cm}^{2}$ tissue culture flasks were inoculated with $1 \mathrm{ml}$ of inoculum. After $1 \mathrm{~h}$ of absorption, the inoculum was removed and fresh medium was added. The infected cells were then incubated at $28^{\circ} \mathrm{C}$ and examined daily for 1 month under a phase-contrast inverted microscope. The successive passages of the virus were performed by adding $0.5 \mathrm{ml}$ of the viral suspension to monolayer NTU-PN-HH cells in $25-\mathrm{cm}^{2}$ tissue culture flasks with $4 \mathrm{ml}$ complete TNM-FH medium. Cell cytopathic effects were observed and photographed. The viral suspension was collected for subsequent use as an inoculum and stored at $4^{\circ} \mathrm{C}$.

\section{Virion Purification}

Isolation and purification of the virus were carried out with several modifications as described in previous papers (Chou et al., 1996; Wang et al., 1998). Briefly, when a cytopathic effect was observed, the cells and viral suspension were harvested from the plastic flasks using rubberpolicemen, collected into 50-ml corning tubes, and then centrifuged for $5 \mathrm{~min}$ at $400 \mathrm{~g}$. The suspension was used directly for viral purification. The pellet was resuspended in STE buffer $(0.15 \mathrm{M} \mathrm{NaCl}$; $0.02 \mathrm{M}$ Tris; $1 \mathrm{mM}$ EDTA; $0.5 \% \mathrm{NP}-40$ ) for $5 \mathrm{~min}$ at $4^{\circ} \mathrm{C}$ under agitation and then homogenized by repeated $(3 \times)$ liquid nitrogen freeze-thaw cycle. The suspension and the treated pellet were then centrifuged together for $30 \mathrm{~min}$ at 15,000g, and the supernatant was ultracentrifuged for $1.5 \mathrm{~h}$ at $100,000 \mathrm{~g}$. The pellet was resuspended in $0.05 \mathrm{M}$ Tris buffer (pH 7.5), deposited onto a 20 to $60 \%$ (w/v) sucrose gradient, and ultracentrifuged for $2.5 \mathrm{~h}$ at $120,000 \mathrm{~g}$. The viral band was collected and diluted with $3 \times$ volume of the same buffer; then the virus was concentrated by ultracentrifugation (2 h, 100,000g). The resulting pellet was resuspended in $1 \mathrm{ml}$ of Tris buffer, layered on a discontinuous gradient of equal volumes $(1.5 \mathrm{ml})$ of $30 \%$ and $60 \% \mathrm{CsCl}(\mathrm{w} / \mathrm{v})$, and ultracentrifuged for $20 \mathrm{~h}$ at $200,000 \mathrm{~g}$. The light-scattering, opalescent band of virus particles was removed from the gradient. The density of the viral particles in $\mathrm{CsCl}$ was determined by using a refractometer to measure the refractive index of an aliquot of the fraction $(0.1 \mathrm{ml})$. The remainder of the aliquot was diluted 100-fold in Tris buffer and then concentrated at $100,000 \mathrm{~g}$ for $1.5 \mathrm{~h}$. The pellet was suspended in $100 \mu \mathrm{l}$ of Tris buffer and frozen at $-20^{\circ} \mathrm{C}$ until further use.

\section{Light and Electron Microscopy}

The infected cells were prepared as described in a previous paper (Wang et al., 1996). Briefly, for the light microscopy, $3 \times 10^{6}$ NTU-PN-HH cells were seeded onto coverglasses in a $25-\mathrm{cm}^{2}$ tissue culture flask. After cells were attached, the medium was removed and $0.5-1.0 \mathrm{ml}$ viral suspension was added. The viral suspension was removed after $1 \mathrm{~h}$ of inoculation at $28^{\circ} \mathrm{C}$ and fresh medium was added. The coverglasses were removed from the flask at 1 and 2 weeks postinoculation and fixed in Carnoy's fixative for $20 \mathrm{~min}$. After hydration, the fixed cell were stained in $0.1 \%$ aqueous acridine orange for 5 min (Humason, 1979) and then rinsed in distilled water and observed under a fluorescence microscope (Olympus BX-50F LA).

For electron microscopy, the infected cells were harvested from the flask using rubberpolicement and centrifuged for $10 \mathrm{~min}$ at $400 \mathrm{~g}$. The cell pellets were fixed in $2.5 \%$ glutaral dehyde in $0.1 \mathrm{M}$ phosphate buffer (pH 7.2), for $3 \mathrm{~h}$ at $4^{\circ} \mathrm{C}$ and postfixed in $1 \% \mathrm{OsO}_{4}$ in the same buffer for $2 \mathrm{~h}$ at $4^{\circ} \mathrm{C}$. After washing in doubledistilled water at $4^{\circ} \mathrm{C}$, the fixed materials were then dehydrated in an alcohol gradient series and embedded in Spurr epon. Thin sections were cut with a Reichart OMU 3 ultramicrotome and stained with uranyl acetate and lead citrate. The electron micrographs were taken with a Hitachi H7100 electron microscope operated at an accelerating voltage of $100 \mathrm{kV}$.

For negative staining, a drop of purified virus was placed on a carbon-coated grid for $3 \mathrm{~min}$ and excess virus suspension was removed with filter paper. A drop of $2 \%$ aqueous solution of phosphotungstic acid was then placed on the grid, excess stain being removed from the grid with filter paper. The preparation was allowed to dry before examination.

\section{Viral Genomeand Protein}

Nucleic acid extraction. The purified virions were incubated for $30 \mathrm{~min}$ at $4^{\circ} \mathrm{C}$ in an extraction buffer (100 $\mathrm{mM}$ Tris- $\mathrm{HCl}, 10 \mathrm{mM}$ EDTA, pH 8.0) containing $2 \%$ $(\mathrm{w} / \mathrm{v})$ SDS and $200 \mu \mathrm{g} / \mathrm{ml}$ proteinase K (Boehringer Mannheim) and then treated twice with phenolchloroform-isoamyl alcohol (25: 24: 1) followed by a chloroform-isoamyl alcohol (24: 1) extraction. The nucleic acid was then ethanol-precipitated in the presence of $0.2 \mathrm{M} \mathrm{NaCl}$ and rinsed with $70 \%$ ethanol. The type and standardization of the nucleic acid were established by treatment with DNase (DNase I, RNasefree; Gibco BRL) and RNaseA (Boehringer Mannheim) followed by electrophoresis. The RNA size was estimated by electrophoresis in formaldehyde-denaturating $1 \%$ agarose gels, and retention of the RNA by an oligo(dT) cellulose column was used to detect the presence of poly(A), according to the methods recommended by the manufacturer (Gibco BRL). 
SDS-polyacrylamide gel electrophoresis. Polypeptide profiles were analyzed by SDS-PAGE on $16 \%$ gels (Laemmli, 1970). After electrophor etic separation, the gel was stained with Coomassie brilliant blue R-250. Molecular weights of the polypeptides were determined by comparison with standard proteins of a known broad-range molecular weight marker (Bio-Rad).

\section{RESULTS}

\section{Cytopathic Effects of I nfected NTU-PN-HH Cells}

The inocula from PnPV and PenuNPV mixedinfection larvae were free of the rod-shape baculovirus, PenuNPV, in negative staining preparation for el ectron microscopic observation, and they did not produce any of the cytopathic effects associated with nucleopolyhedrosis in limiting dilution tests. In addition, lowmagnification electron microscopic observations of PnPV-infected cells provided further combinative evidence. So far, we have propagated PnPV in our cell line, NTU-PN-HH, for more than a half year without any symptoms caused by PenuNPV being found in the infected cells.

Cytopathic effects of NTU-PN-HH cells were first observed at 7 days postinoculation. Cells were enlarged, nuclei were moderately swollen, and many nucleolus-like particles were observed. I rregular particles surrounded the nuclei, especially in squamous NTU-PN-HH cells. Round inclusion bodies (IBs) were found initially at 8 days postinoculation. Most of the I Bs were of approximately the same size, about $1 \mu \mathrm{m}$ in diameter, but a few irregular larger IBs were also

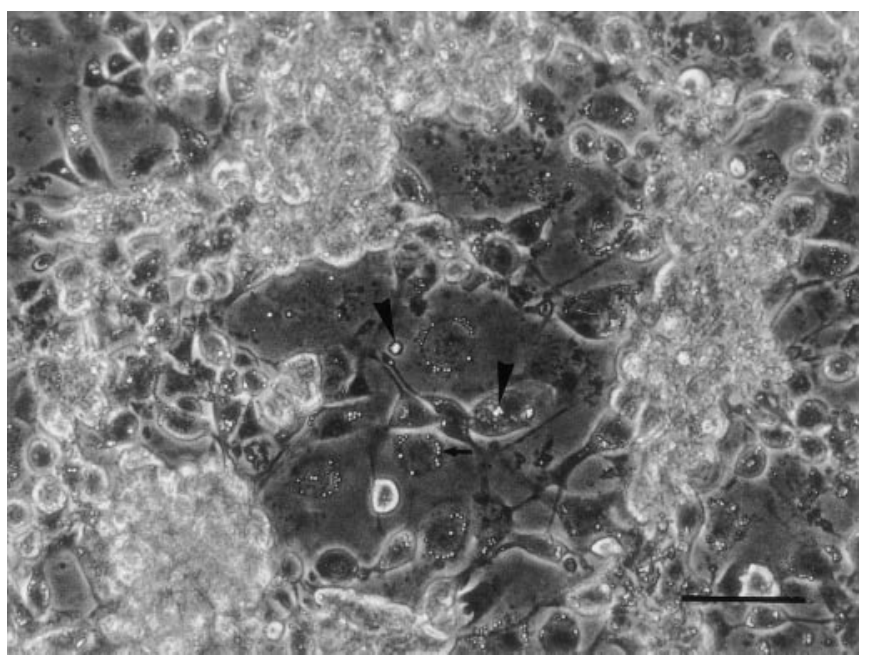

FIG. 1. NTU-PN-HH cells infected with PnPV at 15 days postinoculation. The cytoplasm of the infected cells was filled with round inclusion bodies (IBS), and a few irregular larger IBs were al so found (arrowheads). The IBs formed a ring surrounding the nuclei in the cytoplasm of squamous cells (arrow), whereas a linear or random distribution of IBs was found in other types of cells. Bar, $50 \mu \mathrm{m}$.

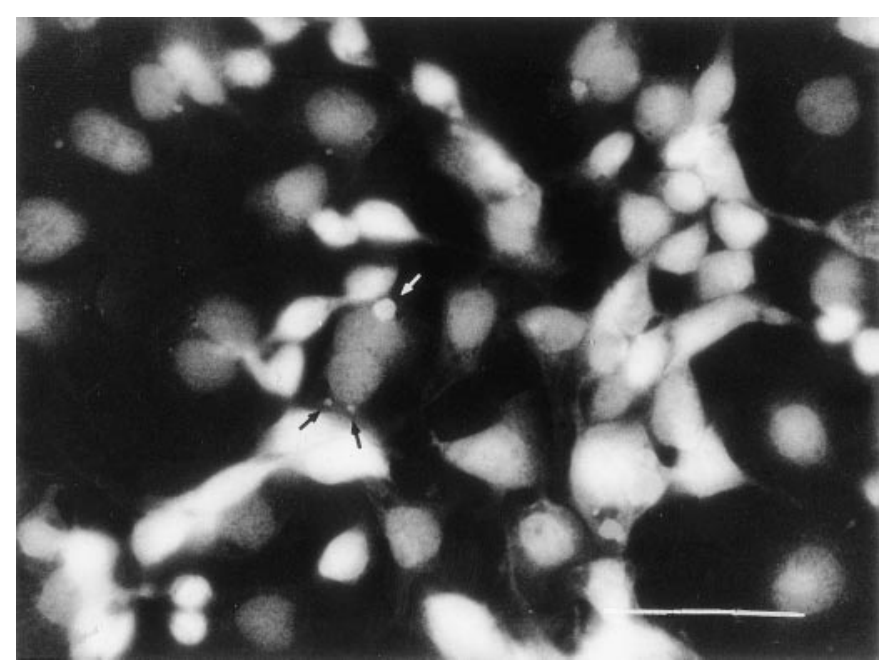

FIG. 2. Acridine orange staining of the infected cells at 1 week postinoculation. The cytoplasm of infected cells showed small orangered fluorescent bodies (arrows). Bar, $50 \mu \mathrm{m}$.

found. About 15 days postinoculation, the infected NTU-PN-HH cells showed an obvious cytopathic effect (Fig. 1). The cytoplasm of infected cells was filled with IBS. The IBs formed a ring surrounding the nucleus in the cytoplasm of squamous NTU-PN-HH cells, whereas a linear or random arrangement of IBs was found in other types of cells. Apart from moderate swelling and changes in the nucleolus-like particle content, other morphological changes in the nuclei of infected cells could not be seen by light microscopy. Subsequently, most of the infected cells became full of vacuoles and Iysed. Eventually, after prolonged infection, they detached from the flask.

Acridine orange staining of the infected cells showed small orange-red fluorescent irregular particles and fluorescent bodies about $1 \mu \mathrm{m}$ in diameter in the cytoplasm (Fig. 2). The morphology of these bodies coincided with that of the IBs as seen under the phase-contrast microscope. The orange-red fluorescence confirmed that the nucleic acid insidethe IBs was single stranded.

An electron micrograph of the negative preparation of the purified virus from in vitro propagation in NTU-PN-HH cells is shown in Fig. 3. The virus is a 30-nm-diameter isometric virus with no envelope and no distinct surface structure.

Electron micrographs of virus-infected cells are shown in Fig. 4A-D. Most of the infected cells contained many round membrane-bound IBs, 0.3 to $1.1 \mu \mathrm{m}$ in diameter (Fig. 4A), which were filled with randomly dispersed (Fig. 4B) or a crystalline array (Fig. 4C) of uniform isometric, nonenveloped particles. Some IBs released their PnPV virus contents, forming vacuoles in the cytoplasm (Fig. 4A). The mitochondria of infected cells became condensed, intermembrane space could not be 


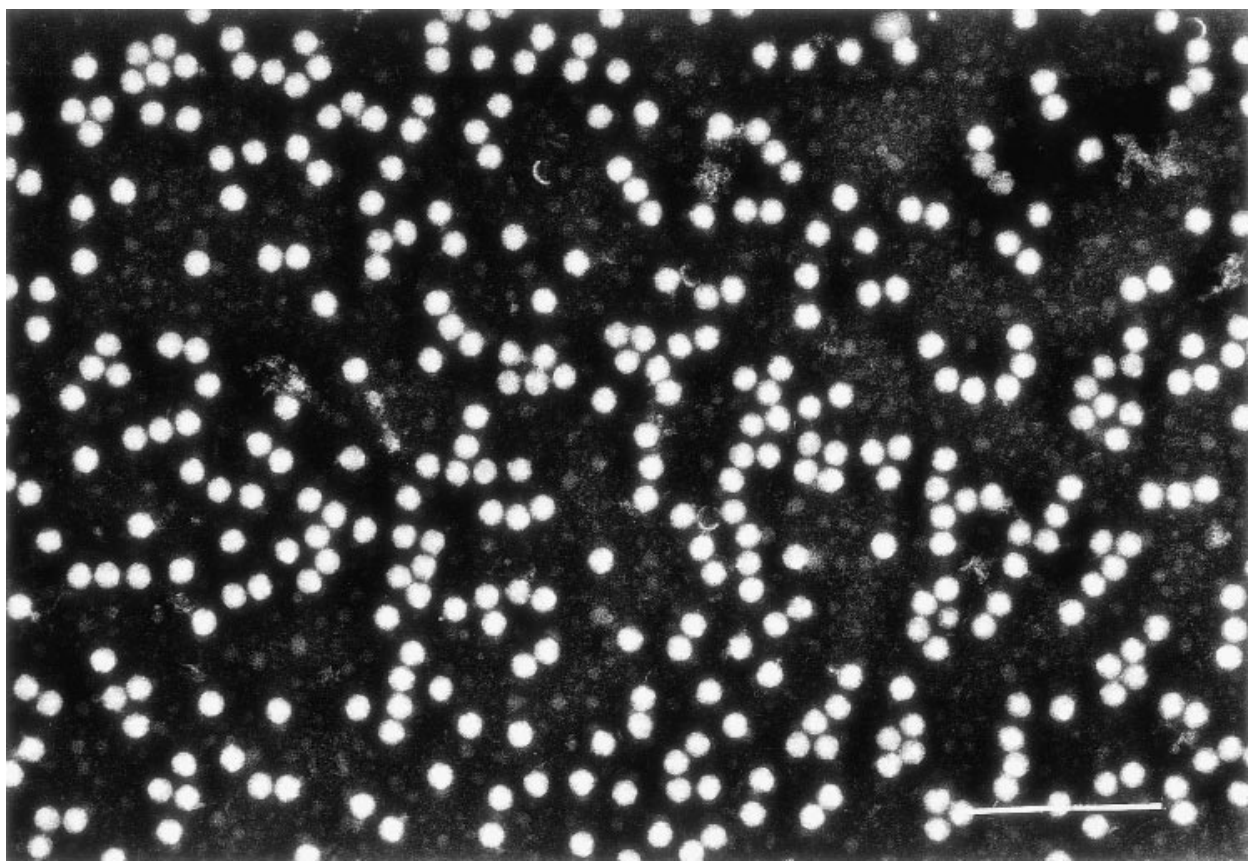

FIG. 3. Electron micrograph of the negative preparation of the purified PnPV from in vitro propagation in NTU-PN-HH cells. Bar, $0.2 \mu m$.

distinguished, and fewer cristae and less matrix space were observed (Fig. 4B). No virogenic stroma could be found. However, a few infected cells contained large crystalline bodies of protein, which contained only a few viral particles; immature viruses surrounded the crystalline bodies (Fig. 4D). In seriously infected cells, the cytoplasm was almost filled with viral particles, which were membrane bound or randomly distributed, and except for the nucleus, the cell organelles could not be distinguished (data not shown).

\section{Characterization of PnPV}

Viral preparations formed two sharp bands on $\mathrm{CsCl}$ gradients (data not shown). The upper band consisted of accumulated debris from the host, and the lower band contained homogeneous isometric particles approximately $30 \mathrm{~nm}$ in diameter as seen in Fig. 3. The buoyand density of the viral particle was $1.381 \mathrm{~g} / \mathrm{ml}$ in $\mathrm{CsCl}$. Electrophoresis of the viral structure proteins from purified viral particles in $16 \%$ gel revealed the presence of three major bands $(31.5,29.7$, and 28.4 $\mathrm{kDa}$ ) and three minor bands (27.0, 24.5, and $4.0 \mathrm{kDa})$ (Fig. 5A). The extracted nucleic acid was resistant to DNase, whereas it was completely digested by RNase A under highly saline conditions $(0.3 \mathrm{M} \mathrm{NaCl})$. Electrophoresis of nucleic acid extracts in formal dehyde-denaturing $1 \%$ agarose gels yielded one band from which the length of the nucleic acid was estimated at $10 \mathrm{~kb}$ (Fig. 5B). Most of the viral genome was bound to an oligo(dT) column, and el ution with the appropriate buffer showed that the RNA contained a poly $(\mathrm{A})$ tract. Thus both this result and the evidence from acridine orange staining confirm that the viral particle contains a single strand of RNA. We therefore conclude that this newly isolated virus belongs to the family Picornaviridae and we propose the name PnPV (Perina nuda picorna-like virus).

\section{DISCUSSION}

Pasteur (1870) recognized four kinds of silkworm disease: flacherie (dysenteries), muscardine (fugal infection), pebrine (protozoan infection), and jaundice (baculovirus infection). The causal agent of flacherie disease in silkworm was identified as infectious flacherie virus (IFV) (Aizawa et al., 1964) or (FVS) (Himeno et al., 1974). The characteristics of IFV were determined and it was assigned to the Picornaviridae (Ayuzawa, 1972; Hashimoto and Kawase, 1983; Kawase et al., 1974; Moore et al., 1985). Flacherie in silkworm was also found to be caused by mixed infection of two (a picornavirus and a densovirus) or four closely related viruses (FVS I-IV) (Himeno et al., 1979; Tanada and Kaya, 1993). Symptoms similar to those seen in silkworm with flacherie are also seen in P. nuda larvae, and these too can be caused by mixed infection, in this case by PenuNPV and PnPV, a picorna-like virus (Wang et al., 1998). The baculovirus, PenuNPV, was originally identified as the key pathogen in an epizootic nucleopolyhedrosis of $P$. nuda that occurs from spring to early summer every year in Taiwan and mainland China (Su et al., 1983; Wang and Tsai, 1995). PenuNPV shows a 

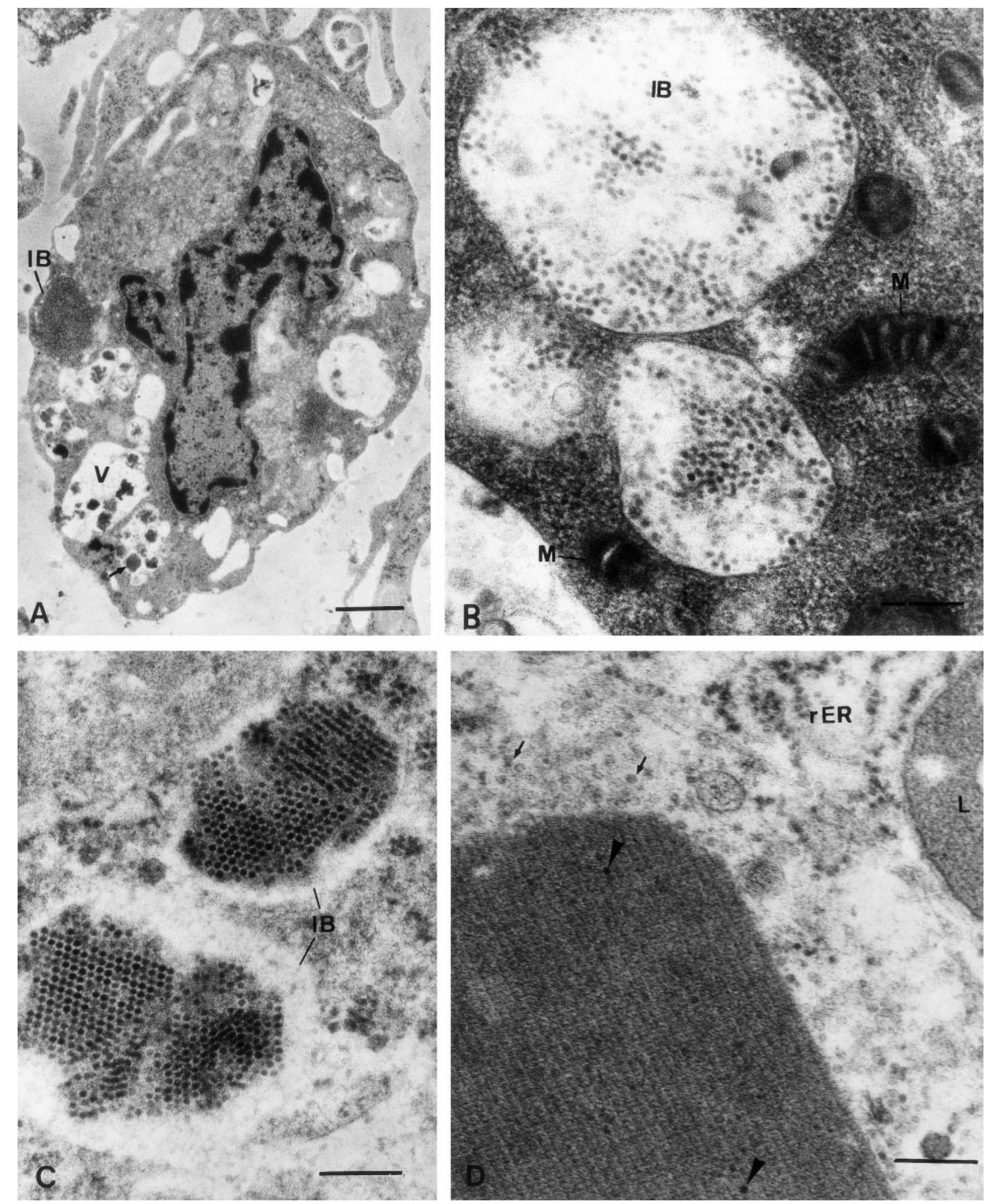

FIG. 4. Electron micrographs of the infected cells. (A) Low magnification of an infected cell. Note the vacuolation of the cytoplasm of the infected cell. Some of these vacuoles (V) were formerly inclusion bodies (IB) from which most of the PnPV virus (arrow) has been rel eased. A membrane-bound IB containing a crystalline arrangement of PnPV cab al so be seen in the cytoplasm. Bar, $1 \mu \mathrm{m}$. (B) High magnification of the IBS, which were filled with randomly distributed, uniform isometric, nonenveloped particles or (C) crystalline arrays. (D) An infected cell containing a large proteinous crystalline body. Only a few native virus particles can be seen in the body (arrowheads) and a few immature viruses are nearby (arrow). Bar, $0.2 \mu \mathrm{m}$. (B, C, and D are at the same magnification). M, mitochondria; $L$, lysosome; $r E R$, rough endoplasmic reticulum. 
A

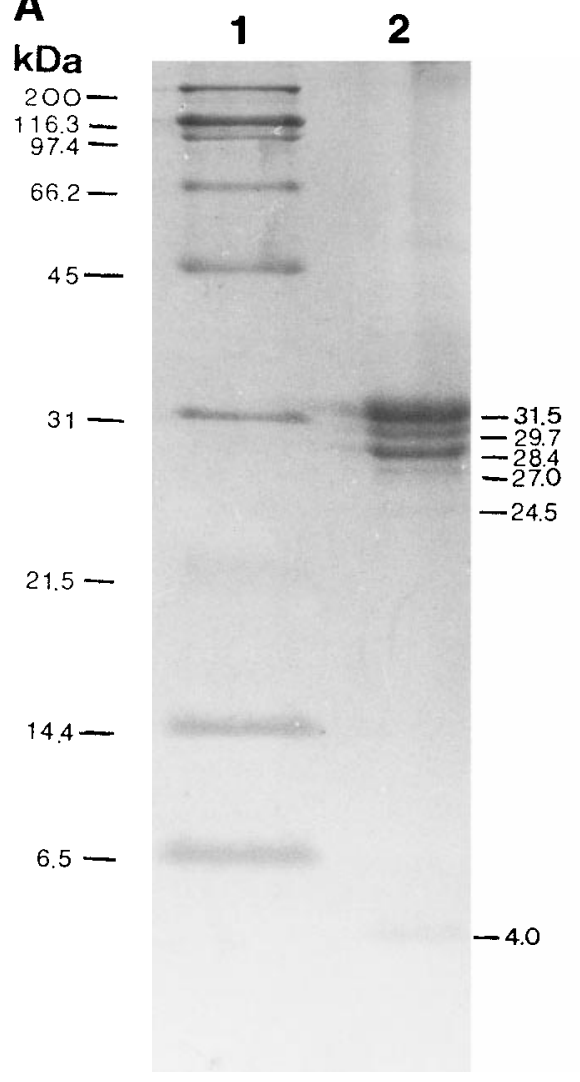

B

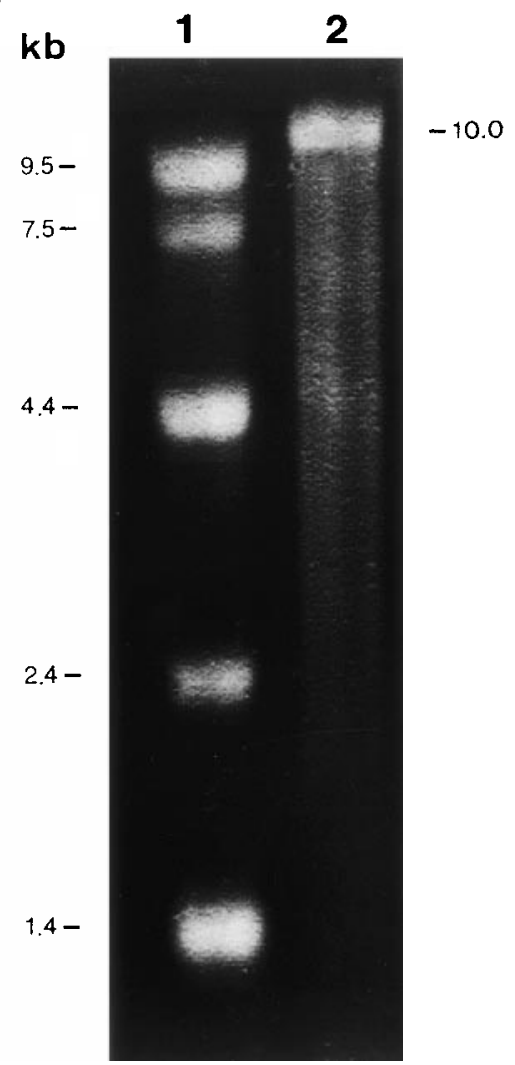

FIG. 5. (A) Structural proteins of PnPV in a $16 \%$ SDS-polyacrylamide gel. Lane 1 , broad-range protein markers (Bio-Rad); lane 2 , structural proteins of PnPV. (B) Genomic RNA of PnPV stained with ethidium bromide in a denaturing $1 \%$ agarose gel containing formaldehyde. Lane 1, RNA size markers (RNA Ladder; Gibco BRL); lane 2, genomic RNA of PnPV.

high virulence to P. nuda larvae, in which it causes jaundice-like symptoms, and it is also highly virulent toward the established NTU-PN-HH cell line (Wang et al., 1996). A mixed infection of PenuNPV and PnPV in P. nuda larvae, on the other hand, produces dysenteric symptoms similar to those seen in silkworm with flacherie. Although such a mixed infection is also fatal, PnPV alone shows a low pathogenesis to the NTU$\mathrm{PN}-\mathrm{HH}$ cell line after experimental infection. Furthermore, experimental PnPV infection of 2nd or 3rd instar larvae of P. nuda by oral treatment and hemocoelic injection suggested that PnPV alone has only a low virulence to P. nuda larvae. In fact, several larvae recovered from infection (Wang et al., 1998), and the only discernible net effect on these recovered larvae was that their growth had been delayed. Paradoxically, this would likely be beneficial to the larvae because they would no longer be in direct competition for limited food resources with healthy P. nuda larvae, and they would thus have a better chance of completing their lifecycle. We therefore suggest that the persistent infection of PnPV may play an important enhancing role in maintaining the natural population density of $P$. nuda.
The in vitro propagation of two insect picornaviruses, cricket paralysis virus (CrPV) and Drosophila $\mathrm{C}$ virus (DCV), in D. melanogaster cells was first successfully achieved in the early 1980s (Moore and Pullin, 1982; Moore et al., 1981). Recently, a persistent infection of GmclV (Galleria mellonel la cell line virus, Picornaviridae) in a G. mellonella cell line was also reported, and in the presence of MSBV, a maize stem borer picornalike virus isolated from Seasamia cretica, observable cytopathic effects have also been induced (Lery et al., 1997). In the present paper, we report for the first time the successful propagation of PnPV in its homogenous cell line, NTU-PN-HH. Although the in vitro pathogenesis of PnPV to the NTU-PN-HH cell line is relatively low compared with that of PenuNPV (Wang et al., 1996), when we compared our unpublished data on the paracrystalline structure of PenuNPV polyhedra with the crystalline body of protein shown in Fig. 4D, the patterns of the two paracrystalline structures were quite different. The successful in vitro propagation of PnPV in NTU-PN-HH cells should greatly facilitate the further study of this virus.

More than 25 small, RNA-containing viruses, including the three insect picornaviruses, CrPV, DCV, and 
Gonometa virus, remain unassigned as of the 1995 ICTV (The International Committee on Taxonomy of Viruses) (Murphy et al., 1995). PnPV is a small virion (30 nm in diameter) containing three major proteins with molecular weight around $30 \mathrm{kDa}$, and the genome consists of a single polyadenylated SSRNA molecule with a length of $10 \mathrm{~kb}$. Despite the unassigned status of the 3 insect pi cornaviruses listed above, these characteristics make PnPV very similar to the other known members of the Picornaviridae, and we are therefore reasonably confident in assigning PnPV to this family. Following our successful in vitro propagation of PnPV, further studies of the biology of PnPV, including its phylogenetic position and genomic structure, are now in progress.

\section{ACKNOWLEDGMENT}

This study was supported by the National Science Council under Grant NSC 87-2313-B-002-050, Republic of China.

\section{REFERENCES}

Aizawa, K., Furuta, Y., Kutata, K., and Sato, F. 1964. On the etiologic agent of the infectious flacherie of the silkworm, Bombyx mori (Linnaeus). Bull. Seric. Exp. Sta., Tokyo 19, 223-240.

Ayuzawa, C. 1972. Studies on the infectious flacherie of the silkworm, Bombyx mori L. I. Purification of the virus and some of its properties. J . Seric. Sci. J apan 41, 338-344.

Chou, C. M., Huang, C. J ., Lo, C. F., Kou, G. H., and Wang, C. H. 1996. Characterization of Perina nuda nucleopolyhedrovirus (PenuNPV) polyhedrin gene. J . I nvertebr. Pathol . 67, 259-266.

Hashimoto, Y., and Kawase, S. 1983. Characteristics of structural proteins of infectious flacherie virus from the silkworm, Bombyx mori. J . Invertebr. Pathol . 41, 68-76.

Hink, W. F., and Strauss, E. 1976. Growth of the Trichoplusia ni (TN-368) cell line in suspension culture. In "Invertebrate Tissue Culture, Applications in Medicine, Biology, and Agriculture" (E. Kurstak and K. Maramorosch, Eds.), pp. 297-300. Academic Press, New York.

Himeno, M., Onodera, K., and Tanami, Y. 1974. Properties of flacherie virus of the silkworm, Bombyx mori. J . Invertebr. Pathol. 23, 164-171.

Himeno, M., Maeda, M., Aoki, H., and Komano, T. 1979. Biochemical and biophysical properties of flacherie virus of silkworm. J . Invertebr. Pathol. 33, 348-357.

Humason, G. L. 1979. "Animal Tissue Techniques." Freeman, San Francisco.

Kawase, S., Suto, C., Ayuzawa, C., and Inoue, H. 1974. Chemical properties of infectious flacherie virus of the silkworm, Bombyx mori L. (Lepidoptera: Bombycidae). Appl. Entomol . Zool . 9, 100-101.

Laemmli, U. K. 1970. Cleavage of structural proteins during assembly of the head of bacteriophage T4. Nature(London) 227, 680-685.

Lery, X., Fediere, G., Taha, A., Salah, M., and Giannotti, J . 1997. A new small RNA virus persistently infecting an established cell line of Galleria mellonella, induced by a heterologous infection. J . Invertebr. Pathol. 69, 7-13.

Moore, N. F., Pullin, J. S. K., Crump, W. A. L., Reavy, B., and Greenwood, L. K. 1981. Comparison of two insect picornaviruses, Drosophila C and cricket paralysis viruses. Microbiologica 4, 359-370.

Moore, N. F., and Pullin, J . S. K. 1982. Plaque purification of cricket paralysis virus using an agar overlay on Drosophila cells. J . Invertebr. Pathol. 39, 10-14.

Moore, N. F., Reavy, B., and King, L. A. 1985. General characteristics, gene organization and expression of small RNA viruses of insects. J. Gen. Virol. 66, 647-659.

Murphy, F. A., Fauquet, C. M., Bishop, D. H. L., Ghabrial, S. A., J arvis, A. W., Martelli, G. P., Mayo, M. A., and Summers, M. D. 1995. "Virus Taxonomy, Classification and Nomenclature of Viruses: Sixth Report of the International Committee on Taxonomy of Virus," pp. 104-113, Arch. Virol. Suppl. 10. Springer-Verlag, Wien.

Pasteur, L. 1870. "Etudes sur la Maladies des Vers à Soie," Tome I. Gauthier-Villars, Paris.

Su, X., Tai, K. C., I, H. T., Shih, M. P., and Hsuan, P. J . 1983. Two nuclear polyhedrosis viruses of two forest insect pests. Sci. Silvae SinicaeMem. For. Entomol. 114-115. [in Chinese]

Tanada, Y., and Kaya, H. K. 1993. Other RNA-viral infections. In "I nsect Pathology," pp. 296-310. Academic Press, San Diego.

Wang, C. H., Wu, C. Y., Chen, W. Y., and Chen, C. W. 1998. Studies on the infectious flacherie of Perina nuda (Fabricius). Chin. J . Entomol 18, 259-271. [in Chinese]

Wang, C. H., Chou, C. M., Liu, H. C., Kau, S. L., Kou, G. H., and Lo, C. F. 1996. Continuous cell line from pupal ovary of Perina nuda (Lepidoptera: Lymantriidae) that is permissive to nuclear polyhedrosis virus from P. nuda. J . I nvertebr. Pathol. 67, 199-204.

Wang, C. H., and Tsai, S. J . 1995. Life history of the Perina nuda (Fabricius) and virus production in the infected pupae. Chin. J . Entomol. 15, 59-68. [in Chinese] 